\title{
Lobbying Behavior of Governmental Entities: Evidence from Public Pension Accounting Rules
}

\section{Citation}

Allen, Abigail, and Reining Petacchi. "Lobbying Behavior of Governmental Entities:Evidence from Public Pension Accounting Rules." Harvard Business School Working Paper, No. 15-043, December 2014.

\section{Permanent link}

http://nrs.harvard.edu/urn-3:HUL.InstRepos:13479073

\section{Terms of Use}

This article was downloaded from Harvard University's DASH repository, and is made available under the terms and conditions applicable to Open Access Policy Articles, as set forth at http:// nrs.harvard.edu/urn-3:HUL.InstRepos:dash.current.terms-of-use\#OAP

\section{Share Your Story}

The Harvard community has made this article openly available.

Please share how this access benefits you. Submit a story.

Accessibility 
H A R VAR D

\title{
Lobbying Behavior of Governmental Entities: Evidence from Public Pension Accounting Rules
}

\author{
Abigail Allen \\ Reining Petacchi
}

\section{Working Paper}

15-043

December 3, 2014 


\title{
Lobbying Behavior of Governmental Entities: Evidence from Public Pension Accounting Rules
}

\author{
Abigail Allen \\ aallen@hbs.edu, 617-495-6222 \\ Harvard Business School \\ Soldiers Field Road \\ Boston MA 02163 \\ Reining Petacchi \\ rnchen@mit.edu, 617-253-7084 \\ Sloan School of Management \\ Massachusetts Institute of Technology \\ 100 Main Street, E62-662 \\ Cambridge, MA 02142
}

November 2014

We thank Roberta Reese and Patti Waterbury of the GASB for generous assistance with sourcing of data. 


\begin{abstract}
We examine the lobbying behavior of state governments in the development of recently issued public pension accounting standards GASB 67 and 68. Consistent with opportunistic motivations, we find that states' opposition to the liability increasing provisions embedded in these standards is increasing in the severity of pension plan underfunding, state budget deficits, and the use of high discount rates. Further we find opposing states are subject to more stringent balanced budget requirements and greater political pressure from unions. By contrast, we find evidence that the support from financial statement users for these provisions is amplified in states with poorly funded plans and large budget deficits, suggesting government lobbying is misaligned with a public interest perspective. We also find evidence that user support varies by type: internal users (public employees) overwhelmingly oppose the standards, relative to external users (credit analysts and the broader citizenry) but the difference is moderated in states with constitutionally protected benefits. This finding is consistent with the expectation that pension accounting reform will motivate cuts in pension benefits as opposed to increased levels of funding from the governments. Analyses of 2011 and 2012 state pension reforms confirm that states opposed to accounting reform are more likely to cut pension benefits.
\end{abstract}




\section{INTRODUCTION}

This paper investigates the lobbying behavior of governmental entities in the standard setting process. Watts and Zimmerman (1978) suggest that in the private sector a variety of different factors, such as tax, political costs, regulatory concerns, and management compensation, influence corporate lobbying on accounting standards. Since then a series of papers has investigated the motivation behind corporate lobbying (e.g., Schalow 1995; Hill, Shelton, and Stevens 2002; Ramanna 2008) and concluded that economic self-interests motivate lobbying in the private sector. In contrast, in the public sector, there are significantly fewer theoretical underpinnings for the factors affecting the lobbying behavior of governmental entities, and empirically we know little about the extent to which governmental entities participate in the accounting standard setting process. This paper aims to fill this void by examining the comment letters submitted by state governments to the Governmental Accounting Standards Board's (GASB) pension reform project. Specifically, we test whether opposition to proposed accounting changes is a function of expected accounting statement impact and the associated economic consequences and political implications of such changes. To the best of our

knowledge, this is the first paper in the accounting literature that examines the lobbying of governmental entities in the formulation of accounting standards.

In 2012, the GASB's highly contentious, 6-year pension reform project culminated with the issuance of GASB Statements No. 67 Financial Reporting for Pension Plans, and 68 Accounting and Financial Reporting for Pensions. Collectively these statements radically altered both the measurement and recognition requirements for defined benefit public pensions, and as 
such, afford three distinct advantages as a research setting to test governmental lobbying. ${ }^{1}$ First, the magnitude of potential financial statement impact resultant from GASB proposed changes created strong incentives for states to participate in the development of new pension accounting standards. GASB 67 and 68 require recognition of a net present liability which reflects benefits earned as opposed to just contributions currently payable as under previous standards (GASB 25 and 27). The standards also expand the scope of recognition requirements to include employers previously exempted from any recognition due to participation in a cost-sharing plan. Moreover, GASB 67 and 68 require discounting the unfunded portion of the pension liabilities at a market rate as opposed to the much higher expected long term asset return rate currently used to calculate states' disclosed future obligations. ${ }^{2}$ As a result, the pension liability recognized under GASB 67 and 68 is expected to dramatically exceed both previously recognized and previously disclosed obligations under GASB 25 and 27 (Henderson and Mortimer 2014; Munnell 2013).

Second, in the wake of the financial crisis and ensuing recession, heightened public awareness of pension underfunding and its potential ramifications for state and municipal solvency motivated considerable interest in pension accounting. ${ }^{3}$ Of the 1,000 comment letters submitted in response to GASB proposals over $15 \%$ were from users of governments' financial reports. This is advantageous for our empirical analyses, because we are able to leverage the comment letters of both internal and external users (including taxpayers, analysts, independent

\footnotetext{
${ }^{1}$ The GASB's pension reform project focuses on defined benefit plans, which constitute almost all the pension plans offered in the public sector. As of $200783 \%$ of workers in state and local government have access to defined benefit plans and nearly all workers (96\%) who have access to a defined benefit plan choose to participate in it (BLS 2008).

${ }^{2}$ GASB 67 and 68 require discounting of projected benefits using a blended rate that reflects " (1) a long-term expected rate of return on pension plan investments to the extent that the pension plan's fiduciary net position is projected to be sufficient to pay benefits and pension plan assets are expected to be invested using a strategy to achieve that return and (2) a tax-exempt, high-quality municipal bond rate to the extent that the conditions for use of the long-term expected rate of return are not met." Under GASB 25 and 27, disclosed pension obligations were discounting using the long-term expected rate of return.

${ }^{3}$ Examples of mainstream media attention in 2009 to the "crisis" in public pension funding and its link to public pension accounting include the Economist, the New York Times and the Wall Street Journal (http://www.economist.com/node/13983688), (http://www.nytimes.com/2009/08/27/business/27audit.html), (http://online.wsj.com/articles/SB124683573382697889).
} 
research organizations, and governmental employees) to provide a "public interest" benchmark against which to evaluate governmental lobbying. This benchmark is often absent in corporate lobbying studies where user participation is severely limited or is confounded by the fact that commenting users are often themselves also financial statement preparers (Young 2006).

Finally, the GASB's controversial pension reform project spanned over 6 years and generated three due process documents: an Invitation to Comment (ITC) issued in 2009, Preliminary Views (PV) in 2010, and Exposure Drafts (ED) in 2011. The long duration of the due process affords a more complete understanding of the lobbying process, because we are able to examine governments' positions over time as their underlying financial and political situations are evolving. This distinguishes our study from prior research, which usually only focuses on a single due process document (e.g., Kelly 1985; King and O'Keefe 1986; Francis 1987; Hill et al. 2002).

We examine state governments lobbying behavior through an analysis of comment letters submitted in response to the three GASB due process documents. Consistent across these due process documents, we identify four liability-increasing proposals that were focal points of debate and were ultimately adopted in some form in GASB Statements No. 67 and 68. We classify state's comment letters as either opposing, neutral or supporting on each proposal and aggregate these positions to arrive at a single measure of government opposition to proposed changes. While collectively the four proposals are expected to significantly increase the recognized pension liabilities on state governments' balance sheets, the magnitude of the impact varies across states based on their pension plan characteristics. States with larger, poorly funded pension plans and states assuming higher discount rates to calculate their pension liabilities are more likely to experience larger increases in the recognized pension liabilities once these 
proposals are adopted. Therefore, we hypothesize that opposition to proposed changes will be increasing in these conditions.

Likewise, we expect the real economic consequences associated with proposed changes to vary across states. The accounting recognition of larger pension liabilities may negatively impact governments' credit ratings, cost of capital, and their ability to borrow. Moreover, the revelation of previously hidden liabilities may incent greater public scrutiny and demands for real pension reform. We expect these economic consequences are magnified in states that are already fiscally stressed, heavily reliant on debt financing, and facing strict balanced budget constraints. Therefore, we hypothesize that states opposition to GASB proposals will be increasing in outside debt burden, fiscal deficit, and budgetary constraints.

Finally, we expect that state governments' lobbying positions may also reflect varied political considerations. First, states with higher corruption levels are more prone to agency problems between government officials and their constituents. Corrupt officials may collect bribes or solicit votes for granting more generous retirement packages to public employees. Since politicians have a limited horizon, it is in these officials' interests to hide pension problems so that they can avoid public scrutiny when they are in office. Second, union strength may also affect the government's stand on the proposed pension reform. Because of their influences on elections, unions are a powerful constituency. Since a higher level of pension obligations may lead to benefit cuts, unions are likely to oppose the proposed rules and this preference may reflect in state's lobbying positions. We also investigate whether state governments' lobbying preferences are associated with their political visibility. Larger states and states running gubernatorial elections tend to attract more media attention and at a higher risk of public outcry. 
These states may be under more pressure to "do the right thing" and lobby in favor of reform on pension reporting.

Our sample consists of 74 comment letters of state governments and 155 letters of their primary financial statement users responding to at least one due process document. The financial statement users include state government employees, municipal bond analysts, rating agencies, professional research groups, and the broader public citizenry.

Consistent with our hypotheses, we find the potential for adverse financial statement effects and economic consequences is associated with states' submissions of negative comment letters. States lobbying against the proposed rules tend to have worse funded pension plans and use more aggressive discount rate assumptions. Furthermore, these states are also more likely to be running deficits and facing strict balanced budget restrictions. We also find evidence that state lobbying reflects political pressures: smaller states and states under strong union influences are more likely to oppose the new rules.

The above findings, while consistent with opportunism might alternatively reflect public interest motivations if users perceive the new standards as either too costly to implement or inconsistent with their perceptions of the underlying economic reality of state pensions. We vet this possibility by examining financial statement users' comment letter positions. Opposite to the results on state lobbying, we find user support for the GASB's proposals is increasing in the magnitude of pension underfunding and state budget deficits. These results suggest that user demand for improved financial reporting varies inversely with state incentives to obscure poorly funded pensions and that state opposition to proposed changes is misaligned with a public interest perspective. We also document systematic variation across user types: internal users (public employees) overwhelmingly oppose liability increasing proposals relative to external 
users (credit analysts, rating agencies, and the general citizenry). This difference is attenuated in states with constitutionally protected pension benefits, consistent with the interpretation that pension accounting reform is likely to trigger benefit cuts as opposed to increased funding from the governments.

We conclude our paper by exploring the relationship between state lobbying positions and the ensuing pension reforms. Drawing on our analysis of user preferences we distinguish between pension reforms which negatively impact employees (cut benefits, reduce eligibility, increase employee contributions) and those which effectively tax the broader citizenry (increase state funding). From 2011 to 2012 we find evidence that while the unconditional occurrences of these two types of reforms are roughly equal, state opposition to the GASB's accounting proposals has a marginal impact of $37 \%$ on the likelihood that a state will cut pension benefits as opposed to increase funding. We also find that the choice to cut benefits is moderated by union strength; conditional on reform, the marginal impact of a one standard deviation increase in public sector unionization decreases the likelihood of benefit cuts by $22 \%$.

Our paper makes several contributions to extant literature. First, we are unaware of any other papers that provide evidence on government lobbying in the accounting standard setting process; others in the literature have focused exclusively on corporate lobbying (e.g., Schalow 1995; Hill et al. 2002; Ramanna 2008). Second, our setting allows us to contrast the views of financial statement preparers with the views of financial statement users to evaluate the perceived impact of a new proposed accounting change. Limited by the scarcity of user participation in standard setting, other papers have largely concentrated on preparers' perspective (e.g., Kelly 1985; Francis 1987; Dechow, Hutton, and Sloan 1996). ${ }^{4}$ Third, evidence on the

\footnotetext{
${ }^{4}$ A small number of papers in the private sector have also studied the standard setting process from audit firms' perspective. For example, Puro (1984) and Allen, Ramanna and Roychowdhury (2013).
} 
relationship between state lobbying positions and subsequent pension reforms adds to the literature linking accounting choice and economic behavior (Fields, Lys and Vincent 2001). Finally, our paper is current in that we study a rule change that will dramatically reshape the reporting of public pensions, one of the largest liabilities our governments bear, and a source of considerable scrutiny in recent years due to severe underfunding.

The remainder of the paper is organized as follows. Section 2 provides background information about the GASB's reform on public pension reporting. Section 3 develops hypotheses pertaining to state government and user lobbying. Section 4 discusses research design and Section 5 reports the results. Section 6 presents the analysis of subsequent state pension reform initiatives and Section 7 concludes.

\section{BACKGROUND}

Pension obligations constitute the single largest debt owed by states governments. As of 2005 , total reported state pension obligations totaled $\$ 2.5$ trillion compared to $\$ 798$ billion in non-pension debt (Novy-Marx and Rauh 2008). Pension obligations are offset by pension assets, however historical underfunding coupled with depressed asset portfolio values resultant from the Financial Crisis and subsequent recession has created a severe crisis in pension funding. As of 2013, conservative estimates showed funding deficits of \$915 billion (Pew 2014) with many believing the true number to be in excess of $\$ 4$ trillion. ${ }^{5}$

Disagreement and opacity surrounding the true magnitudes of government pension liabilities has largely been anchored in a debate between two distinctly different approaches for the measurement and reporting of pension costs: an actuarial funding based approach and a

\footnotetext{
${ }^{5}$ Novy-Marx \& Rauh (2011) estimate a \$3.1 trillion gap in state and local pension funding as of 2009. Rauh (2011) updates the figure to $\$ 4.4$ trillion as of 2011.
} 
financial economics based approach. Under GASB Statements No. 25 Financial Reporting for Defined Benefit Pension Plans and Note Disclosures for Defined Contribution Plans and 27 Accounting for Pensions by State and Local Governmental Employers the accounting for public pension plans largely preserved a "funding" perspective, under which recognized liability and expenses were directly linked to a states' annual required contributions while the much larger unfunded actuarial accrued liability (UAAL) was relegated to footnote disclosure and utilized long-term expected asset return rates to discount projected benefits. In its official Report on the Municipal Securities Market, the Securities and Exchange Commission (SEC) alleged that under this approach "trillions of dollars in liabilities - reflecting amounts promised to state and local government workers - are not appropriately reflected on government books, thereby seriously misleading investors about the riskiness of their investments in municipal securities" (SEC 2012). On the other hand, proponents of existing accounting rules contended that a funding focus "promotes decision usefulness", and "best ensure[s] alignment between projected and actual funding of pension liabilities" consistent with the objectives of "interperiod equity" and "the perpetual nature of governments" (NASRA 2009; NASACT 2009).

Acknowledging this contentious debate, the GASB added a project on pension accounting to its research agenda in 2006, issued an Invitation to Comment (ITC) in 2009, Preliminary Views (PV) in 2010, companion Exposure Drafts (ED) in 2011 and finally, final Statements No. 67 Financial Reporting for Pension Plans, an amendment of GASB Statement No. 25 and 68 Accounting and Financial Reporting for Pensions, an amendment of GASB Statement No. 27 in 2012. Representing a dramatic shift from the status-quo funding-oriented approach of GASB 25 and 27, GASB 67 and 68 contain 4 central provisions expected to dramatically increase the magnitude of pension liabilities recognized by state governments. 


\section{Governmental employers must recognize a liability for the unfunded portion of their pension obligations (Net Pension Liability) on their balance sheets. ${ }^{6}$}

Measured as the difference between the overall pension obligation and the fair value of assets accumulated in the plan, GASB asserted that Net Pension Liability (NPL) meets the definition of a liability under Concept Statement No. 4 and as such, must be recognized on the face of employers' financial statements. The underlying justification is that pension benefits are a form of compensation, which governments provide in return for work; accordingly they must be recognized in the period earned. This concept is in stark contrast to the funding oriented approach in the old regime where the accrued net pension obligation (NPO) recognized only those liabilities which were currently due and payable in accordance with the terms of the plan. ${ }^{7}$ By recognizing an obligation for benefits earned, not just benefits due, NPL places a substantially larger liability on employers' balance sheets than did NPO.

\section{Employers participating in cost-sharing plans must recognize a proportionate share of the net pension liability. ${ }^{8}$}

A cost-sharing multiple employer plan pools assets across participating governments resulting in shared risk and shared obligation for funding shortfalls. ${ }^{9}$ Accordingly, assets of a cost-sharing plan can be used to pay any employee's benefits, regardless of what participating government they work for. Traditionally, this shared-obligation arrangement exempted

\footnotetext{
${ }^{6}$ In governmental accounting a balance sheet is called a "Statement of Net Assets."

${ }^{7}$ Under GASB 25 and 27, NPO is equal to the cumulative difference between annual required contributions and the employers' actual contributions to its plan.

${ }^{8}$ Proportional allocation is according to the contribution rates of each participating employer. (See GASB 68 paragraphs 48-50).

${ }_{9}^{9}$ Public pension plans can be either single-employer or multiple-employer. Single employer plans involve only one government, whereas multiple employer plans include more than one government. Multiple employer plans generate economies of scale by pooling investments together and sharing administrative costs among participating governments. A multiple employer plan can either be agent multiple employer or cost sharing multiple employer. An agent multiple-employer plan is very similar to a single employer plan in that it maintains a separate account for each participating government to ensure that the assets accumulated within the account are used to provide benefit payments only for the employees of that government. This is very different from a cost-sharing multiple employer plan where no separate accounts are maintained.
} 
employers from financial statement disclosure of actuarial information on their pension obligations. Instead, fund-level only information could be obtained from the pension plan's financial statements. Critics argued, and the GASB concurred, that this presentation obscured the underlying obligations of these employers and precluded meaningful comparisons between costsharing and non-cost sharing governments (IFTA 2010; Moody’s 2012).

\section{Unfunded pension liability should be discounted using a market-based rate of return as opposed to the expected long-term rate of return on plan assets.}

Determining the appropriate discount rate for the promised pension payments was one of the most controversial issues in the GASB's pension project. Historically, total pension obligations were discounted using the expected long-term rate of return on the investments of the plan assets, regardless of funding levels. Proponents of this approach argued the expected rate of return "best reflects the employers projected sacrifice of resources" and the "going-concern" nature of governmental entities (GASB 2011). However, critics contended that since the expected rate of return on assets does not reflect the risk of the promised payments, using this rate as the discount rate downwardly biases the measurement of public pension liabilities (e.g., Novy-Marx and Rauh 2009, 2011) and incentivizes governments to invest in high-risk assets (Lucas and Zeldes 2009).

Responding to its critics, the GASB initially proposed to adopt a market based discount rate, proposing for discussion in its ITC several options, including a risk-free treasury rate, the employer's borrowing rate, and high quality municipal bond yields. Significant opposition to such a stark change ensued, and during the PV and ED stages, the Board softened its position, proposing and ultimately adopting a "blended rate" that incorporates both the expected rate of return on assets and the high quality municipal bond rate. The rationale is that if the plan assets are sufficient to make pension payments in the long term, using long term expected rate of return 
on assets as a discount rate reflects the underlying asset-coverage of plan liabilities. Where assets are projected to be insufficient, however, benefits are discounted using the high quality municipal bond rate, which more accurately reflects the risk of these un-covered benefits.

The "blended rate" solution has been heavily criticized by economists and regulators as leaving room for employers to "hide the true extent of underfunding" and failing to eliminate incentives to "burn cash" and "chase yield" (SEC 2014). Notwithstanding, given that a market based rate is typically smaller than the expected rate of return assumed by the governments, using a blended rate to discount the promised benefits was generally acknowledged by critics as a step in the right direction that would increase recognized pension liability, particularly for the worst funded plans. ${ }^{10}$

\section{Ad hoc cost of living adjustments (COLAs) should be included in the computation of total pension liability.}

Ad hoc COLAs are upwards adjustments in pension benefit terms not specifically written into the pension provisions. Despite the fact that many states grant ad-hoc COLA's on a fairly regular basis, because they are at the government's discretion, historically they have been excluded from benefit projections. ${ }^{11}$ Ultimately adopted, the GASB's proposal to include ad-hoc COLAs in the calculation of projected benefits will increase the total pension liability.

\section{HYPOTHESIS DEVELOPMENT}

\footnotetext{
${ }^{10}$ For example, during 2005-2010, the average expected rate of return assumed by the state governments is about $8 \%$, while average Treasury yield is about $4.8 \%$. Applying the GASB's "blended rate" methodology, the average funded ratios for municipal plans are expected to drop from 73\% to 60\%. (Munnell et al. 2013).

${ }^{11}$ The GASB's proposals also identify other items (automatic COLAs, future salary increases, and future service credits) to be included in total pension liability. However, these other proposals were less contentious as they were already components of disclosed UAAL; we focus on ad hoc COLAs because they were unique to the proposed new measurement of NPL.
} 
Sutton (1984) uses Downs' (1957) voting model and identifies the conditions under which rational lobbying will occur. He suggests constituents engage in lobbying when both the probability of regulatory influence and the expected gains from influence are sufficient to outweigh the costs of lobbying. Within the private sector, prior research postulates that while the costs are largely born by the firm (i.e. shareholders), it is management who instigates lobbying and therefore gains from lobbying may not always be value-maximizing. Specifically, research in standard setting has investigated predictions that lobbying may reflect both shareholdercongruent incentives to increase cash flow and conflicting agency incentives to maximize manager's personal wealth, often by obscuring or manipulating accounting information (e.g., Deakin 1989; Dechow et al. 1996).

Lobbying by governments on accounting regulation to the best of our knowledge has not been specifically examined either empirically or theoretically in prior literature; however, we propose that agency conflicts are analogously relevant to this context. Similar to a firms' obligations to its shareholders, state governments have fiduciary responsibilities to their constituencies (including employees, general tax-base, and creditors) to lobby in favor of accounting alternatives which will increase transparency, facilitate operationally efficient allocation of resources, and enable objective evaluation of elected officials performance. The dismal state of public pension funding at current provides compelling motivation for increased transparency and accounting reform. On the other hand, lobbying may also be impacted by the self-serving incentives of officials to obscure poor performance and fiscal distress. The economic and political ramifications of reported higher pension liabilities are likely to weigh heavily on voters perception of public officials. Elected officials, concerned with public approval ratings or seeking re-election, may accordingly have incentives to obscure the underlying distress in 
pension systems. Likewise, political pressure from unions, who may have interests in obscuring the true costs of pensions in order to deter cuts in benefits or to negotiate more generous packages, may influence elected officials' preferences for reform. Thus, state government lobbying is likely to reflect both the public interest concerns of its citizenry and the selfinterested incentives of those officials elected to represent them.

We investigate government lobbying behavior by evaluating state governments' opposition to liability increasing provisions in GASB 67 and 68 proposals. In particular we test the influence of three potential drivers of government lobbying: expected financial statement impact, economic consequences, and political costs.

\section{H1. Financial statement impact:}

The magnitude of balance sheet impact resultant from the GASB's proposed accounting changes varies by state according to their pension plans' characteristics. Larger, more severely underfunded plans as well as plans assuming higher rates of return on plan assets are expected to experience larger increases in reportable net pension liabilities (Mortimer and Henderson 2014). On average in 2010 states reported total pension obligations of $\$ 57$ billion, were $27 \%$ underfunded to meet such obligations, and employed an assumed rate of return (discount rate) exceeding comparable market rates by $3-4 \%$ (Standard \& Poor's 2012). Mortimer and Henderson (2014) estimate that implementing GASB 68 in 2010 would have on average increased states' reported net pension liabilities by $\$ 9.2$ billion with a widely dispersed range from $\$ 230$ million for the Wisconsin Retirement System to $\$ 79$ billion for the California Public Employees Retirement System. ${ }^{12}$

\footnotetext{
${ }^{12}$ Mortimer and Henderson (2014) compare their projected estimates of GASB 68 net pension liability (NPL) to unfunded actuarially accrued liability (UAAL), a figure previously only disclosed in required supplementary
} 
We conjecture that the probability of lobbying in opposition to the GASB's proposals is increasing in the magnitude of expected adverse financial statement effects brought about by GASB 68. Accordingly Hypothesis H1 is that: Ceteris paribus, state government opposition to the GASB's pension proposals is increasing in the potential enlargement of a state's reported pension liability as proxied by its current total pension obligation, percentage funded ratio, and discount rate assumptions.

\section{H2. Economic consequences:}

The financial statement impact of increased pension liabilities is relevant only to the extent that it generates adverse economic consequences for state governments (or state officials). Due to the free riding problem, lobbying should be concentrated amongst those for whom the economic consequences of adverse financial statement impact are the greatest (Zeff 1978; Sutton 1984). In our setting, the balance sheet impact of increased pension liability has potential contracting implications for state governments who rely heavily on debt financing. By increasing the magnitude of pension liabilities reflected on governments' balance sheets, new pension accounting standards increase the expected costs associated with renegotiation, refinancing and/or technical default. Additionally, higher leverage ratios may induce credit rating downgrades, which diminish access to and increase cost of capital. ${ }^{13}$ Although evidence from leasing suggests creditors may effectively monitor and price off-balance sheet obligations (Wilkins and Zimmer 1986; Altamuro, Johnston, Pandit, and Zhang, 2014), users contended that in the old regime the significant latitude in estimating the present value of pension obligations

information. Under GASB 27, governments report a net pension obligation (NPO) on their balance sheets and NPO is in general significantly smaller than UAAL. Therefore the balance sheet impact from adopting the new standards is likely substantially larger than the estimated $\$ 9.2$ billion.

${ }^{13}$ Moody's 2009 rating methodology report indicates that a government's overall debt burden and the magnitude of its pension obligations are important determinants of its credit ratings. Similarly, S\&P (2014) suggests the agency incorporates government liability management, including pensions, in its rating analysis. 
augmented with opacity of cost-sharing plan disclosures generate barriers to assessing the true impact of outstanding pension liabilities on government fiscal conditions for even sophisticated users (IFTA 2010; Moody's 2013). Thus we postulate that state opposition to the GASB's pension accounting proposals will be increasing in a state's reliance on debt financing.

By increasing the magnitude of reported pension liabilities, the GASB's new pension proposals are likely to increase scrutiny around pension funding deficits and thus increase pressure on states to improve funding. Given that most states have some form of balanced budget requirements prohibiting deficit spending over any prolonged period of time, fiscally stressed states are constrained in their ability to increase pension funding without raising taxes or reducing fiscal outlays elsewhere. Chaney, Copley, and Stone (2002) provide evidence that when fiscally stressed, states with strict balanced budgets provisions simultaneously underfund pensions and strategically manipulate the assumed rate of return on assets to obscure such underfunding. GASB proposals would both reduce the flexibility to manipulate pension assumptions and increase the visibility of current pension underfunding. Thus, in aggregate, we expect the economic impact of the GASB's pension accounting proposals is more pronounced for fiscally stressed states and for states facing rigorous anti-deficit rules.

Summarizing the above arguments, Hypothesis $\mathrm{H} 2$ is that: Ceteris Paribas, opposition to the GASB's pension proposals is increasing in the potential for adverse economic consequences arising from the debt contracting and fiscal budgeting implications of financial statement changes.

\section{H3. Political factors:}

Elected officials are also likely to internalize political motivations when lobbying on pension reform. In particular economic theory suggests when policy actions are observable, 
politicians may manipulate current policy at the expense of future economic performance in order to increase their chances of re-election (Harrington 1993). In our setting, labor unions constitute a powerful constituency, intensely vested in the outcome of pension reform and likely to weigh on an official's re-election calculus. Pension benefits constitute a significant percentage of total compensation paid to public employees and are frequently the target of union negotiations. ${ }^{14}$ Since pension benefits are promised future benefits, they can be granted with a smaller impact to a state's current budget than direct wage increases. According to a Senate Joint Economic Committee report, abetted by the cash oriented budgeting approach of governments, "the largest de facto component of states deficit spending is unfunded pension liabilities" (2012 pg. 2). Naughton, Petacchi, and Weber (2014) provide evidence that when the "true-costs" associated with pension benefits are understated state officials tend to overinvest in employee payroll. Given this link between pension reporting and labor spending, we postulate GASB proposals may rationally be opposed by unions fearing cuts to pension benefits and/or loss of future negotiating leverage as a result of the increased magnitude and transparency of state reported pension liabilities. To the extent that state officials are sensitive to union pressures this preference may manifest in state opposition to reform. On the other hand, underfunding of pensions is an issue salient not only to employees but to a politician's broader electorate and tax base. Public media, tax-advocacy groups and general public sentiment demanding pension reform may represent a countervailing political force to union opposition. Thus we expect that the efficacy of union pressure on state officials to lobby against GASB pension reform will vary according to the relative strength of public sector unions within that state.

\footnotetext{
14 Accordingly to data from the U.S. Bureau of Labor Statistics defined benefit pension benefits on average constitute $7 \%$ of total public sector employee compensation as compared to $1.5 \%$ for private sector. http://www.bls.gov/news.release/archives/ecec 09102009.pdf accessed 09/23/2014.
} 
Corruption of state officials may also influence a states' propensity to lobby against the GASB's proposals. Higher state corruption levels are likely correlated with intentional mismanagement or neglect of state pension funds, increasing the incentives for officials to conceal such mismanagement through opaque accounting. It is also possible that political visibility affects a state's lobbying position. Larger states, being more visible to national media and regulatory scrutiny, may under more pressure to reform and be less likely to oppose the proposed changes. In addition, because scrutiny of public official's actions is likely accentuated in election years, political pressures may play a more prominent role during state election years, particularly when elections are highly contested. By advocating for the GASB's proposals elected officials may hope to project an image of public stewardship and fiscal responsibility acknowledging the need for change and affirming commitment to reform.

Summarizing the above arguments, Hypothesis H3 is that: Ceteris Paribas, opposition to the GASB's pension proposals is increasing in the potential for adverse political costs arising from union pressure, corruption, and political visibility.

\section{Determinants of user opposition to GASB proposals}

Evidence that state opposition to the GASB proposals varies predictably according to expected accounting impact, economic consequences and political influences as hypothesized in $\mathrm{H} 1$ through $\mathrm{H} 3$ does not ipso facto provide evidence of state lobbying opportunism. In particular, critics of the proposed accounting changes argued that the new rules require governmental entities to disclose a substantial amount of information that is costly to compile. If the benefits of the proposed rules are not large enough to outweigh the associated compliance burden, or if the proposed rules, while intended to increase transparency, in reality created a misleading or inaccurate picture of state pension obligations, state opposition to the changes might be aligned 
with the public interest. To obtain a clearer picture, we empirically explore the determinants of user lobbying behavior in response to the proposed accounting changes. If state lobbying is motived by politician self-interest rather than public interest, we would expect user support for the proposed changes is increasing in those same variables predicted to increase state opposition. That is, we hypothesize (H4) that user support is increasing in the magnitude of expected adverse financial statement impact, economic consequences, and political ramifications of proposed accounting changes.

\section{DATA AND RESEARCH DESIGN}

\subsection{Sample selection}

We use multiple public data sources to construct our sample. We collect the comment letters in response to the due process documents from the GASB. Letters in the PV and ED stages are available for download from the GASB's online archive. We obtain letters in the ITC stage by direct request from the GASB staff. Data on state sponsored defined benefit pension plans are obtained from the Boston College Center for Retirement Research; missing data is sourced directly from the plan's Comprehensive Annual Financial Reports and valuation reports. Our sample includes 107 state sponsored pension plans, which are further aggregated to state level for analysis. We classify whether a state sponsors cost sharing pension plans based on a 2013 report published by Moody's. Data for state financial condition variables are collected from Census Bureau's Annual Survey of Governments and National Association of State Budget Officer's fiscal survey of states. We collect public employee union membership data from unionstats.gsu.edu, which compiled the data from the Current Population Survey (Hirsch and Macpherson 2003). We collect the number of corruption convictions of local, state, and federal 
officials from the U.S. Department of Justice. Election and population data are from the U.S. Census Bureau.

Table 1 Panel A shows that $36(72 \%)$ of the 50 states submitted comment letters in at least one stage of the GASB's due process with total participation of 74 (49\%) observations across the due process. These 74 observations constitute the sample for our tests of state lobbying position on proposed increases in recognized pension liability. Our second sample is the 155 comment letters from 121 distinct primary users of the state governments' financial statements. We categorize these users into three groups: (1) EMPLOYEE includes state government employees and government employee affiliated organizations, (2) ANALYST includes rating agencies and municipal bond analysts, and (3) CITIZEN includes individual citizens, taxpayer advocacy groups, and other research organizations. Interestingly, we observe that for governments, participation is significantly higher at earlier stages of the due process (ITC and PV), consistent with the premise that preparers have incentives to lobby early-hoping to shape the proposed regulation - rather than at later stages when regulatory direction is largely set. By contrast, user participation is most pronounced in the final stage of project development (ED) consistent with the idea that salience of the issue to users has increased over time.

Table 1 Panel B provides further breakdown of user participation revealing roughly equal participation by individuals and representative organizations. $72 \%$ of users have state-specific affiliations and $28 \%$ are national organizations (primarily national unions, municipal analyst organizations, and credit rating agencies). Overall, users from 24 distinct states participated in some stage of the GASB due process. ${ }^{15}$

\footnotetext{
${ }^{15}$ Of the 24 distinct states represented in the user sample, 15 are overlapping with the 36 distinct states represented in our state-government sample. Thus, 45 distinct states are represented in the union of our government and user samples.
} 


\subsection{Comment letter coding}

For the 74 state and 155 user comment letters in our sample, we manually coded each letter as expressing opposition, support or neutrality for each of the 4 central provisions in the GASB's pension reform proposals expected to substantially increase the pension liability recognized by state governments. Although the specific language surrounding these provisions evolved with due process over time, these 4 provisions were consistently central issues in the GASB's pension reform project, proposed and discussed extensively in every stage of the deliberation. We provide detailed wording of the GASB's proposals related to these 4 provisions in each of the ITC, PV and ED stages in Appendix A along with the specifics of our coding rubric.

We classify letters as opposing (coded 1) if they express direct opposition to the proposal, or request their states be exempted in its implementation. We classify letters as supporting (coded -1) if they express support for the proposal, or call for alternatives which would further increase pension liability relative to the GASB's proposal. We classify letters as neutral (coded 0 ) if they explicitly express a neutral stance, or do not express an opinion on the proposal. ${ }^{16} \mathrm{~A}$ combined measure of a constituent opposition (OPPOSE) is calculated as the sum of constituent responses across the 4 provisions. OPPOSE ranges from -4 to 4 , with higher values indicating greater opposition to the proposed changes.

\subsection{Predicting state and user opposition to the proposed accounting changes}

\footnotetext{
16 The GASB due process documents are accompanied by questions on key proposals to which commenters are explicitly invited to respond. Accordingly, it seems reasonable to assume that comment letters omitting a response on a specific proposal do so deliberately because they are neutral toward the proposal or deem the proposal inconsequential to the point that no response is merited.
} 
We use the following ordered logit model to predict the lobbying position of commenting states and users:

$$
\begin{array}{r}
\operatorname{Pr}(\text { OPPOSE })=\text { QFinancial Statement Impact }+ \text { ГEconomic Consequences }+ \text { SPolitical } \\
\text { Factors }+\Lambda \text { Controls }+\Sigma \text { Year Fixed Effects }+\varepsilon
\end{array}
$$

where our dependent variable, OPPOSE, measures the extent to which the commenter opposes the 4 GASB proposals, if passed, expected to increase the reported pension liability. We include the following pension plan characteristics to test whether lobbying opposition is increasing in the potential for adverse financial statement impacts. PENSIONL measures the size of the pension liability and is defined as the reported actuarial accrued pension liability scaled by total tax revenues. FUND_RATIO is the funding ratio and is equal to the actuarial value of pension assets divided by the actuarial accrued liability. The higher the FUND_RATIO, the better the plan is funded. INV_ASSUMP is the reported long-term expected investment return on pension assets and is the discount rate used to value total pension liability under GASB 27. Together PESIONL, FUND_RATIO, and INV_ASSUMP provide good proxies for the relative increase in pension liabilities states will be required to recognize under the new standards. COST_SHARE is an indicator variable equal to 1 if the state sponsors cost sharing plans. We include this variable because proposal 4 is specifically related to cost sharing plans and for states not sponsoring such plans they are likely to have different lobbying incentives from states sponsoring these plans.

We include the following financial condition variables to test whether lobbying is increasing in the severity of economic consequences likely to accrue from financial statement changes. DEFICIT measures the extent to which the state is running a deficit and is defined as per capita general fund expenditures minus per capita general fund revenues after adding back any midyear spending cuts or tax changes. We undo these midyear adjustments to uncover the 
true fiscal condition of the state. ${ }^{17}$ DEBT measures the extent to which the state is relying on debt financing and is defined as per capita outstanding non-pension related long-term debt minus any offsets to debt (e.g., cash and security holdings in debt service fund or sinking fund). BBR measures the stringency of the state's balanced budget provisions based on the index produced by the Advisory Commission on Intergovernmental Relations (ACIR 1987). The variable ranges from 0 to 10 , with higher values indicating more rigorous balanced budget provisions. ${ }^{18}$ Pension plan characteristics and state financial variables are matched to the comment letters with a one year lag, because it usually takes a long time for state governments to compile and issue their financial reports after fiscal year end. ${ }^{19}$

We include the following political factor variables to test the relationship between political pressure and state lobbying position. USTRENGTH measures the strength of the union in the state government and is defined as the proportion of public sector state employees who are members of a labor union or of an employee association similar to a union. CORRUPT measures the public employee corruption level within a state. The variable equals 1 if the per capita corruption convictions of local, state, and federal officials are greater than the sample median and 0 otherwise. ELE is an indicator variable equal to 1 if the year is a gubernatorial election

\footnotetext{
${ }^{17}$ Failure to undo the midyear adjustments obscures the true fiscal condition of the state. For example, assume during the fiscal year the governor learns that due to revenue shortfalls, expenditures are expected to exceed revenues by $\$ 2$ million. To prevent the state from running a deficit, the governor carries out a midyear spending cut of $\$ 3$ million, resulting in a final surplus of $\$ 1$ million. Without undoing the midyear adjustment, we would incorrectly conclude that the state is doing well in the fiscal year. See more discussion on the importance of these adjustments in Poterba (1994).

${ }^{18}$ In addition to the ACIR classification of budget rules, there are other classification systems (see for example, the General Accounting Office 1993; National Conference of State Legislatures 2010). As Clemens and Miran (2012) point out, the General Accounting Office (1993) classification scheme is closely related to the ACIR (1987) index. Our results are qualitatively similar if we use the National Conference of State Legislatures (NCSL) 2010 system. We prefer to use the ACIR (1987) system in our main analysis because NCSL (2010) uses a more simplified ditochomas system. Moreover, prior research examining the effect of balanced budget provisions on state budgeting also relies on the ACIR (1987) system (e.g., Poterba 1994; Clemens and Miran 2012).

${ }^{19}$ A research brief issued by the GASB in March 2011 suggests that on average it takes about 7 months for state governments to complete their financial reports after fiscal year end. The completion date is not the actual date the report is posted to a government's website or otherwise became available. Therefore, the actual issuance delay is even longer (GASB 2011).
} 
year and 0 otherwise. Since a state's lobbying incentives may be different when the election is competitive, we further allow the coefficient on ELE to be different for a competitive election by interacting ELE with COMP, where COMP equals 1 if the winning candidate's vote is between $49 \%$ and $51 \%$. LnPOP measures the size of the state and is defined as the natural logarithm of the state population.

When predicting user's lobbying positions, we make the following adjustments to equation (1). First, when the user is a national organization or represents multiple states, we take the mean values of the state-specific variables of the states the user represents. ${ }^{20}$ In addition, we control for heterogeneity in user incentives by including two user type indicator variables, EMPLOYEE and ANALYST, omitting the third user type CITIZEN. We also include state fixed effects to control for state heterogeneity, because we find that users from certain states (e.g., California, Ohio) are more likely to lobby than other states perhaps in part due to organized campaigns. ${ }^{21}$

In all our analyses, we cluster standard errors by state to correct for possible correlations across observations of a given state (Petersen 2009). Appendix B lists detailed definitions of variables.

\section{RESULTS}

\subsection{Descriptive statistics}

\footnotetext{
${ }^{20}$ For example, the International Federation of Professional and Technical Engineers (IFPTE) submitted a comment letter in response to the Exposure Draft. The organization represents state and local government workers in the following 5 states: New Jersey, California, Rhode Island, Connecticut, and Illinois. We take the average of these 5 state's variables to construct state-specific variables.

${ }^{21}$ State fixed effects include separate indicator variables to capture national organizations and organizations representing multiple states.
} 
Table 2 shows opposition to the GASB's proposals by constituent type. OPPOSE has a mean value of .97 for state governments, which suggests that on average state governments lobby against the GASB's proposals that will increase the reported liability. However, we also observe wide heterogeneity in state's position; OPPOSE ranges from -4 to 4 with a standard deviation of 2.01. Across the three types of users, public employees are most likely to oppose the new proposals, whereas credit analysts and citizens on average support the new proposals; the mean value of OPPOSE is 1.18 for public employees compared to -1.25 for credit analysts and 0.73 for citizens. As with state governments however we observe a wide range of positions even within each user group.

Table 3 reports summary statistics on state government's pension plan, financial, and political conditions over the sample period. On average reported pension liability is about four times larger than a state's total tax revenues, only $81 \%$ funded by plan assets, and is calculated using a long-term asset return assumption of about $8 \%$. COST_SHARE has a median value of 1 , which suggests that the majority of states sponsor cost sharing plans. An average state runs a deficit of $\$ 39$ per capita during the sample period, borrows $\$ 476$ per capita of long-term debt per year, and is $32 \%$ unionized. About $30 \%$ of the sample years have a gubernatorial election, and $14 \%$ of the elections are considered competitive.

\subsection{Determinants of state lobbying position on the proposed accounting changes}

Table 4 reports the results on states' lobbying positions. Columns [1] to [3] show that OPPOSE is decreasing in FUND_RATIO and increasing in INV_ASSUMP, which suggests states lobbying against the liability increasing provisions tend to have worse funded pension plans and utilize higher discount rate assumptions. These are precisely the types of states expected to recognize a large increase in pension liabilities once the proposals are adopted. 
Therefore, the result is consistent with the hypothesis that governments' lobbying activities depend on the likely adverse financial statement effects. We also find opposing states tend to be running larger deficits and facing stricter balanced budget restrictions, as indicated by positive coefficients on DEFICIT and BBR in columns [2] and [3]. To the extent that a larger pension liability is likely to increase funding pressure, this result is consistent with the economic consequence hypothesis that fiscally constrained states are more likely to oppose liability increasing proposals. Finally, we find some weak evidence that opposing states tend to rely more heavily on debt financing; the coefficient on DEBT is weakly significant in column [2] but not in column [3].

In column [3] we include political factors and find a positive coefficient on USTRENGTH, which suggests opposing states tend to be under strong union influences. This result is consistent with the argument that due to their large influences on elections, unions' preferences on standard setting may reflect in governments' lobbying activities. We also find political visibility affects governments' lobbying positions; large states as well as states in competitive gubernatorial elections (10\% significance level, one tailed) are less likely to oppose the pension accounting reform.

Overall the results in Table 4 suggest that the lobbying positions a state takes are associated with the effects of the proposed accounting changes on the financial statements, likely economic consequences, and political factors. To the extent that the GASB's proposals are expected to improve measurement and transparency in pension reporting, these results are consistent with the hypothesis that governments' lobbying reflects opportunistic motivations to obscure the true magnitude of pension obligations. However, an alternative explanation is that GASB proposals were perceived as being fundamentally misaligned with economic reality. To 
the extent that proposed changes were expected to result in suboptimal accounting for pensions, or were associated with overly burdensome compliance costs, the results in Table 4 might be consistent with governments' lobbying having been aligned with public interest. To distinguish between these alternative explanations, in the subsequent section we examine the lobbying positions of primary users of governments' financial statements.

\subsection{Determinants of user lobbying position on the proposed accounting changes}

Table 5 presents the results on the lobbying positions of the primary users of state governments' financial statements. We find a positive coefficient on FUND_RATIO and a negative coefficient on DEFICIT, which suggest that users are more likely to lobby in favor of the liability increasing provisions if they reside in states with poorly funded plans and worse financial conditions. We also find some weak evidence that users are more likely to support the new provisions if their states adopt more aggressive investment return assumptions. The coefficient on INV_ASSUMP is negative across columns [1]-[3]; however, it is significant at the conventional level only if we do not include political factor variables. These results are opposite those observed from states' lobbying positions and suggest that state lobbying incentives are inversely related to public interest motivations. Table 5 suggests that users view the new pension rules as a promising way to reform public pension accounting and that user demand for reform is increasing in state mismanagement of pension liabilities in the prior regime.

We also find that the support for the provisions varies across user types. Internal users (government employees) overwhelmingly oppose the liability increasing provisions relative to external users (credit analysts and general citizens). We interpret this finding as consistent with the expectation that GASB's pension reform project is likely to motivate states to cut benefits rather than to increase levels of funding. To provide additional evidence, we investigate whether 
employees' opposition is mitigated if their pension benefits are protected by state constitutions. We include an indicator variable, PROTECTION, equal to one if the pension benefits of public employees are guaranteed by state constitutions and interact this variable with EMPLOYEE. ${ }^{22}$ Consistent with our expectation, column [4] shows that the coefficient on the interaction term between PROTECTION and EMPLOYEE is negative and significant however, the sum of the coefficients on EMPLOYEE and EMPLOYEE*PROTECTION is still positive and significant ( $p$-value $=0.066)$, suggesting that constitutional protection of pension benefits attenuates but does not eliminate employee opposition to proposed changes.

The findings in Table 5 allow us to speak to the perceived value of the proposed pension reporting reform for financial statement users. To the extent that users submitting letters to the GASB are sufficiently informed and sophisticated to evaluate the costs and benefits of the proposed rules, these findings suggest that the new GASB proposals were perceived as beneficial to external financial statement users, especially those residing in states prone to pension problems. Collectively the contrasting results of Tables 4 and 5 suggest governments' lobbying activities are motivated by politician self-interests, rather than by public interest concern.

\section{STATE PENSION REFORM CHOICES}

We conduct additional analysis examining whether states' lobbying positions are related to their pension reform initiatives. Research on accounting choice suggests that managers take real economic actions in anticipation of adverse accounting changes. ${ }^{23}$ The evidence in Table 4

\footnotetext{
${ }^{22}$ Seven states provide constitutionally guaranteed pension benefits. These states are: Alaska, Arizona, Illinois, New York, Michigan, Hawaii and Louisiana. Three of them are represented in our user sample. Importantly, constitutional protections apply only to current employees and therefore do not preclude states' from offering reduced benefit packages to new employees.

${ }^{23}$ For example, Mittelstaedt, Nichols, and Reiger (1995) show that the financial reporting consequences associated with SFAS 106 Employers' Accounting for Post-Retirement Benefits other than Pensions were related to corporate decisions to cut employee benefits.
} 
suggests that opposition to GASB proposals reflects the expected economic and political ramifications of reporting increased pension liabilities. Accordingly, we hypothesize that opposing states, anticipating such consequences, are more likely to implement real pension reforms aimed at decreasing reportable pension liabilities during the lead up to implementation of GASB 67 and 68.

There are two primary options for a state to reduce outstanding pension liability: (1) reduce costs through benefit cuts, reduced eligibility or increased employee contribution requirements, or (2) increase funding. We test whether state lobbying positions related to the choice between these options by gathering data on all state pension reform initiatives effectuated between 2011 and 2012 as compiled by the Center for State and Local Government Excellence as well as data on the percentage of annual required contributions (ARC) funded by state governments during these years. We use 2011 as the starting point for our analysis, as the GASB's PV, issued late in 2010, represents the first explicit proposal of what eventually became GASB 67 and 68 and therefore is the point at which we expect governments' might first reasonably anticipate and respond to incentives created by expected accounting changes. ${ }^{24} \mathrm{We}$ measure the extent to which a reform reduces pension benefits using an ordinal variable BEN_CUT which takes a value of zero if a state does not initiate reform on benefit cuts, a value of 1 if a state reduces employee benefits or increases required employee contributions for new employees, and a value of 2 when such reforms also apply to current employees. Cutting benefits for current employees in addition to new hires will have a more dramatic impact on reducing pension liabilities but is also likely to be substantially more controversial and therefore

\footnotetext{
${ }^{24}$ At the ITC stage, although the same issues were debated as in the PV and ED stages, there was no explicit sense of the Board's intended direction. Rather alternatives were presented and constituents were asked to weigh in on the relative merits of each. (See Appendix A for examples of the questions asked in the ITC stage.) Notwithstanding, results are robust to including reforms effectuated in 2010 (i.e. those occurring after the ITC stage but before the PV stage).
} 
politically less palatable. We also construct a binary variable INC_FUND which takes a value of 1 if the average percentage ARC funded by a state for 2011 and 2012 is greater than it was from 2009-2010. Finally we construct a binary variable REFORMTYPE which reflects the choice between benefit cuts (REFORMTYPE $=1$ ) and increase funding (REFORMTYPE $=0$ ) for those states who initiate one type of reform or the other, but not both. We use this variable to examine the trade-off between increasing funding and cutting benefits conditional on initiating a reform. ${ }^{25}$ Table 6 Panel A summarizes states' pension reform choices. From 2011 to 2012, 23 states reduce benefits, of which 15 affect only future hires and 8 affect both future and current employees; 21 states increase funding; 11 states do both; and 17 states do neither.

To investigate whether state opposition to the accounting change is related to ensuing real reform, we classify a state as an opposing state $($ D_OPPOSE $=1)$ when the average value of OPPOSE for a state is greater than 0 across the GASB's 3 due process documents. ${ }^{26}$ We then regress BEN_CUT, INC_FUND, and REFORMTYPE on D_OPPOSE using an ordered logit and simple logit specifications as dictated by variable type. We include as controls the underlying economic and political constraints faced by a state. States carrying large deficits or with strict balanced budget restrictions are more likely constrained in their ability to increase funding levels and therefore we expect such states to be more likely to cut benefits. By contrast, given the power of unions over elections and the disparity between internal (government employee) and external (analyst and citizen) user preferences, we predict that benefit cuts will be less likely in states which are heavily unionized. Because the primary driver of reform is likely related to underlying pension distress, we also control for the pension plan characteristics as well as

\footnotetext{
${ }^{25}$ Inferences are similar if we instead define REFORMTYPE as a categorical variable which includes all four potential reform choices: no reform, benefit reduction, funding increases, and both, and analyze using a multinominal logit model.

${ }^{26}$ The results are similar if we focus on the 36 states that participated in the commenting process and run the analysis on OPPOSE, instead of D_OPPOSE.
} 
whether these benefits are constitutionally protected. We average all time varying variables for each state across 2008-2010.

Table 6 Panel B reports regression results. Overall, we find strong evidence that state opposition to GASB proposals is associated with a higher probability of pension reform through benefit cuts: D_OPPOSE is a significant predictor of BEN_CUT (column [1]) but not INC_FUND (column [2]). Moreover, when we directly compare the choices between cutting benefits and increasing funding, we find that opposing states are more likely to cut benefits as opposed to increase funding (column [3]). In particular, opposition to GASB proposals has a marginal impact on the decision to cut benefits (as opposed to increase funding) of $37 \%$. Providing validity to our results we find that pension reform choices vary predictably with economic predictors. Fiscally constrained states and states with large outstanding debts are more likely to cut benefits (column [1]); states facing strict balanced budget constraints are less likely to increase funding (columns [2]). Consistent with internal user opposition to benefit cuts, we also find that the probability of benefit cuts as opposed to funding increases is decreasing in union strength (column [3]) and that the marginal impact of a one standard deviation increase in unionization diminishes the marginal probability of cutting benefits by $22 \%{ }^{27}$ Collectively, Table 6 provides support for the hypothesis that state opposition to proposed accounting reform is associated with ensuing pension reform choices, incremental to the independent fiscal and political drivers of such reform.

\section{CONCLUSION}

\footnotetext{
${ }^{27}$ In the reduced sample underlying column [5], PROTECTION only takes a value of 1 for two states both of which have REFORMTYPE=1. Accordingly PROTECTION and these 2 observations are dropped from analysis. We note that across our entire sample of 50 states the raw correlations between PROTECTION and BEN_CUT and PROTECTION and INC_FUND are statistically indistinguishable from zero.
} 
Using the setting of GASB's recent reform on pension reporting, this study provides empirical evidence on lobbying by governments. Our results are consistent with the hypothesis that government officials lobby in their own self-interests, not in the interests of their constituencies. Specifically, we find state governments' opposition to the new reporting proposals is increasing in the likelihood that they will to face adverse financial statement impact and negative economic consequences once these proposals are adopted. We also find states with strong unions are more likely to lobby against the proposed accounting changes, which suggests governments' lobbying positions may reflect union preferences. In contrast to the results on government lobbying, we find users residing in states with worse pension funding and budgetary conditions are more likely to support the pension accounting reform. This finding suggests government lobbying is misaligned with public interest concerns. We further find that user support varies across user types; internal users (public employees) are more likely to oppose the reform, relative to external users (credit analysts and regular citizens). However, this difference is moderated in states where public employees' benefits are constitutionally guaranteed, consistent with the expectation that pension accounting reform is likely to motivate benefit cuts instead of increased funding from the employers.

We conclude the paper by investigating whether state lobbying positions impact the realization of pension reform choices. We find that opposing states are more likely to rein in future pension liabilities by cutting pension benefits than by increasing funding levels relative to their non-opposing counterparts. We also find that unions constitute a countervailing political force - the likelihood of pension benefit cuts is diminishing in the percentage of public unionization. 
Our paper contributes to existing literature along several dimensions. By studying the nature of the comment letters submitted to the GASB by state governments, we are the first to document government lobbying behavior, while other papers in the literature all focus on corporate lobbying. In addition, we not only study the participation of financial statement preparers in the formulation of accounting standards, but also contrast it to the participation of financial statement users which allows us to better distinguish opportunistic lobbying from public interest. This responds to Gipper, Lombardi and Skinner (2013)'s recent call for more research on how a broader set of constituents participate in the standard setting process. Finally by linking state lobbying to real pension reform choices we provide preliminary evidence on the link between accounting choice and economic outcomes in a public setting. 


\section{REFERENCES:}

Allen, Abigail, Karthik Ramanna, and Sugata Roychowdhury. "The auditing oligopoly and lobbying on accounting standards." Working Paper, Harvard Business School, 2013.

Altamuro, Jennifer, Rick Johnston, Shailendra Pandi, and Haiwen Zhang. "Operating Leases and Credit Assessments." Contemporary Accounting Research 31, no. 2 (2014): 551-580.

Advisory Commission on Intergovernmental Relations. "Fiscal Discipline in the Federal System: National Reform and the Experience of the States. ACIR Report A-107. Washington, DC, (July 1987).

Bureau of Labor Statistics (BLS). "National Compensation Survey: Employee Benefits in State and Local Governments in the United States, September 2007." (March 2008).

Chaney, Copley and Stone. "The effect of fiscal stress and balanced budget requirements on the funding and measurement of state pension obligations." Journal of Accounting and Public Policy 21 (2002): 287-313

Clemens, Jeffrey, and Stephen Miran. "Fiscal Policy Multipliers on Subnational Government Spending." American Economic Journal: Economic Policy 4, no. 2 (2012): 46-68.

Deakin, E. B. "Rational Economic Behavior and Lobbying on Accounting Issues: Evidence from the Oil and Gas Industry." The Accounting Review (1989): 64(1): 137-151.

Dechow, Patricia M., Amy P. Hutton, and Richard G. Sloan. "Economic consequences of accounting for stock-based compensation." Journal of Accounting Research (1996): 1-20.

Downs, A, “An Economic Theory of Democracy.” New York: Harper \& Row (1957).

Fields, Thomas D., Thomas Z. Lys, and Linda Vincent. "Empirical research on accounting choice." Journal of accounting and economics 31.1 (2001): 255-307

Francis, Jere R. "Lobbying against proposed accounting standards: The case of employers' pension accounting." Journal of Accounting and Public Policy 6 (1987): 35-57.

Gipper, Brandon, Brett Lombardi, and Douglas J. Skinner. "The Politics of Accounting Standard-Setting: A Review of Empirical Research." Working Paper, University of Chicago, 2013.

GASB. "Research Brief: The timeliness of financial reporting by state and local governments compared with the needs of users." Norwalk, 2011.

Harrigton, J. "Economic policy, economic performance, and elections" American Economic Review, 83 (1993): 27-42. 
Hill, Nancy T., Shelton, Sandra W., and Stevens, Kevin T. "Corporate Lobbying Behavior on Accounting for Stock-Based Compensation: Venue and Format Choices" Abacus 38, no. 1 (2002): 78-90.

Hirsch, B. T., \& Macpherson, D. A. Union membership and coverage database from the current population survey: Note. Industrial and Labor Relations Review 56 (2003): 349-354.

Hou, Yilin, and Daniel L. Smith. "A Framework for Understanding State Balanced Budget Requirement Systems: Reexamining Distinctive Features and an Operational Definition." Public Budgeting \& Finance, Fall 2006: 22-45.

Institute for Truth In Accounting (IFTA). "Response to Invitation to Comment- Pension Accounting and Financial Reporting by Employers (Preliminary Views)" (2010): 8-10

Kelly, Lauren. "Corporate Management Lobbying on FAS No. 8: Some Further Evidence." Journal of Accounting Research 23, no. 2 (Autumn 1985): 619-632.

King, Raymond D., and Terrence B. O'Keefe. "Lobbying activities and insider trading." The Accounting Review 61, no. 1 (January 1986): 76-90.

Lucas, Deborah J., and Stephen P. Zeldes. "Pensions and Health Care: Fiscal Challenges for State and Local Governments. How Should Public Pension Plans Invest?" American Economic Review 99, no. 2 (2009): 527-532.

Mittelstaedt, H. Fred, William D. Nichols, and Philip R. Regier. "SFAS No. 106 and benefit reductions in employer-sponsored retiree health care plans." Accounting Review (1995): 535-556.

Moody's. "Rating Methodology: General Obligation Bonds Issued Local Governments." October 2009.

Moody's. “Adjusted Pension Liability Medians for US States.” June 27, 2013.

Moody's. "Cross Sector Rating Methodology: Adjustments to US State and Local Government Reported Pension Data." 2013.

Mortimer, John W., and Henderson, Linda R. (2014) "Measuring Pension Liabilities under GASB Statement No. 68." Accounting Horizons 28(3): 421-454.

Munnell, Alicia H., Jean-Pierre Aubry, Josh Hurwitz, and Madeline Medenica. "The Funding of State and Local Pensions: 2012-2016." State and Local Plans Issue in Brief no. 32 (2013).

National Conference of State Legislatures. "NCSL Fiscal Brief: State Balanced Budget Provisions." Washington, DC., (2010) 
Naughton, Petacchi and Weber. "Public pension accounting rules and economic outcomes." Working Paper, MIT (2014).

Novy-Marx, Robert, and Joshua D. Rauh. The intergenerational transfer of public pension promises. No. w14343. National Bureau of Economic Research, (2008).

Novy-Marx, Robert, and Joshua D. Rauh. "The Liabilities and Risks of State-Sponsored Pension Plans." Journal of Economic Perspectives 23, no. 4 (Fall 2009): 191-210.

Novy-Marx, Robert, and Joshua Rauh. "Public Pension Promises: How Big Are They and What Are They Worth?" Journal of Finance, no. 4 (August 2011): 1211-1249.

Petersen, Mitchell A. "Estimating standard errors in finance panel data sets: Comparing approaches." Review of Financial Studies 22, no. 1 (2009): 435-480.

Poterba, James M. "State Reponses to Fiscal Crises: The Effects of Budgetary Institutions and Politics." Journal of Political Economy 102, no. 4 (August 1994): 799-821.

Puro, Marsha. "Audit Firm Lobbying Before the Financial Accounting Standards Board: An Empirical Study." Journal of Accounting Research 22, no. 2 (Autumn 1984): 624-646.

Ramanna, Karthik. "The implications of unverifiable fair-value accounting: Evidence from the political economy of goodwill accounting." Journal of Accounting and Economics 45 (2008): 253-281.

Rauh, J. Kellogg Insight Presents. (2011). Retrieved October 1, 2014, from "Shortfall for State and Local Pension Systems Today: Over \$4 Trillion": http://kelloggfinance.wordpress.com/2011/10/06/shortfall-for-state-andlocalpensionsystems-today-over-4-trillion/.

Schalow, Christine M. "Participation Choice: The Exposure Draft for Postretirement Benefits Other Than Pensions." Accounting Horizons 9, no. 1: 27-41.

Securities and Exchange Commission (SEC) Commissioner Daniel M. Gallagher Speech "Remarks at Municipal Securities Rulemaking Board's 1 ${ }^{\text {st }}$ Annual Municipal Securities Regulator Summit." (May 29, 2014).

Sutton, T. G. "Lobbying of accounting standard-setting bodies in the UK and the USA: a Downsian analysis." Accounting, Organizations and Society 9 (1984): 81-95.

Standard and Poor's. "The Decline In U.S. States' Pension Funding Decelerates, But Reform And Reporting Issues Loom Large" (2012) http://www.standardandpoors.com/spf/upload Ratings_US/The_Decline_In.pdf (accessed 9/29/14)

Standard and Poor's. "U.S. State Pension Funding: Strong Investment Returns Could Lift Funded Ratios, But Longer-Term Challenges Remain.” June 24, 2014. 
Watts, Ross L., and Jerold L. Zimmerman. "Towards a Positive Theory of the Determination of Accounting Standards." The Accounting Review 53, no. 1 (January 1978): 112-134.

Young, J. “Making up users.” Accounting Organizations and Society, no. 31 (2006): 579-600.

Zeff, S. A. "The rise of economic consequences.” Journal of Accountancy (December 1978): 5663. 


\section{APPENDIX A:}

\section{Four Liability Increasing Provisions and the Corresponding Wording in the GASB Due Process Documents}

We list the specific wording corresponding to the 4 liability increasing provisions in each stage of the GASB due process. In the ITC and PV stages, the Board solicits comments by asking questions with potential choices. This simplifies the responses and facilitates our coding. In the ED stage, the Board posits questions in its Exposure Draft Plain-Language Supplement. However, these questions are only for users of governmental financial information, and not for preparers of financial statements. Even users do not always provide comments following these questions. Therefore, the coding in the ED stage is more complicated and we ensure the accuracy of the coding using a dual-coder model in that each of the authors codes the ED comment letters independently. We meet to resolve any disagreement in our assessments.

Below we list the corresponding questions asked in the ITC and PV stages. In the ED stage, rather than listing the exact paragraphs, we describe the proposals using language in the Exposure Draft Plain-Language Supplement. We then identify the corresponding paragraphs in the ED for interested reader.

\begin{tabular}{|r|l|}
\hline 1. & $\begin{array}{l}\text { Governmental employers should be required to recognize a liability for the } \\
\text { unfunded portion of their pension obligations (Net Pension Liability) on their } \\
\text { balance sheets. }\end{array}$ \\
\hline ITC: & $\begin{array}{l}\text { Question 2. What obligations of a sole or agent employer associated with pensions } \\
\text { meet the definition of a liability in Concepts Statement 4 and why? }\end{array}$ \\
\hline a. & $\begin{array}{l}\text { A measure of the cumulative difference between (1) amount expensed, based } \\
\text { on annual required contributions of the employer to the pension plan pursuant } \\
\text { to a program of funding pension benefits developed within established } \\
\text { parameters and (2) the amounts the employer actually has contributed to the } \\
\text { plan. }\end{array}$ \\
\hline b. $\begin{array}{l}\text { A measure of the employers unfunded accrued benefit obligation to employees } \\
\text { for the financial report date related to the employment agreement governing } \\
\text { the exchange of employee services for salaries and benefits. }\end{array}$ \\
\hline c. $\begin{array}{l}\text { Other. (Please identify the obligation that you believe best meets the liability } \\
\text { definition). }\end{array}$ \\
\hline PV: \\
$\begin{array}{l}\text { Question 2b. It is the Board's preliminary view that the net pension liability is } \\
\text { measurable with sufficient reliability to be recognized in the employer's basic } \\
\text { financial statements. Do you agree with this view? Why or why not? }\end{array}$ \\
\hline ED: $\begin{array}{l}\text { Do you agree or disagree with the GASB's proposal that governments recognize } \\
\text { the net pension liability in their financial statements? Why do you agree or } \\
\text { disagree? (See paragraphs 14-16). }\end{array}$ \\
\hline
\end{tabular}


In the ITC stage, there 3 choices the commenter could select to express their views. We code a comment letter as opposed to the proposal if the commenter chose (a), as supportive to the proposal if the commenter chose (b). There were no comment letters in our sample selecting (c).

\begin{tabular}{|c|l|}
\hline 2. & $\begin{array}{l}\text { Ad hoc cost of living adjustments (COLAs) should be included in the } \\
\text { computation of total pension liability. }\end{array}$ \\
\hline ITC: & $\begin{array}{l}\text { Question 4. Should the projection of pension benefits include or exclude the } \\
\text { following projected future changes? Why? }\end{array}$ \\
\hline a. & Automatic COLAs \\
& $\begin{array}{l}\text { b. } \\
\text { Projected future ad hoc COLAs, in circumstances in which ad hoc COLAs are } \\
\text { substantively a part of the employment agreement, as demonstrated by an } \\
\text { employer's pattern of practice. }\end{array}$ \\
\hline c. $\quad$ Projected future salary increases \\
\hline d. Projected future service credits \\
$\begin{array}{l}\text { Question 3a. It is the Board's preliminary view that the projection of pension } \\
\text { benefits payments for purposes of calculating the total pension liability and the } \\
\text { service cost component of pension expense should include the projected effects of } \\
\text { the following when relevant to the amounts of the benefit payments: (1) automatic } \\
\text { COLAs, (2) future ad hoc COLAs in circumstances in which such COLAs are not } \\
\text { substantively different from automatic COLAs, (3) future salary increases, and (4) } \\
\text { future service credits. Do you agree with this view? Why or why not? }\end{array}$ \\
\hline ED: $\begin{array}{l}\text { The GASB is proposing that ad hoc COLAs and other postemployment benefit } \\
\text { changes would be included in benefit projections if an employer's past practice } \\
\text { and future expectations of granting them indicate that they effectively have } \\
\text { become automatic. (See paragraph 20). }\end{array}$ \\
\hline
\end{tabular}

In both the ITC and PV stages, the Board seeks comments on the four potential items to be included in the calculation of projected benefits. However, the most controversial item is the ad hoc COLAs and almost all the comment letters responding to the proposal comment on ad hoc COLAs. Therefore, we focus on ad hoc COLAs in our coding scheme. In the ITC (PV) stage, we code a comment letter as supportive of the proposal if it advocates for including choice $b$ (2).

\begin{tabular}{|c|c|}
\hline 3. & $\begin{array}{l}\text { Total pension liability should be discounted using a market-based rate of return } \\
\text { as opposed to the expected long-term rate of return on plan assets. }\end{array}$ \\
\hline \multirow[t]{3}{*}{ ITC: } & $\begin{array}{l}\text { Question 5. What would be the basis for determining the discount rate used by } \\
\text { discounting projected pension benefits to their present value for accounting } \\
\text { purposes? Why? }\end{array}$ \\
\hline & a. $\quad$ The estimated long-term investment yield for the plan \\
\hline & $\begin{array}{l}\text { b. A risk-free rate (or a yield curve of risk-free rates applied to cash flows of } \\
\text { different maturities) }\end{array}$ \\
\hline
\end{tabular}




\begin{tabular}{|c|c|c|}
\hline & c. & The employer's borrowing rate \\
\hline & d. & An average return on high-quality municipal bonds \\
\hline & & Other \\
\hline PV: & \multicolumn{2}{|r|}{$\begin{array}{l}\text { Question 3c. It is the Board's preliminary view that the discount rate for } \\
\text { accounting and financial reporting purposes should be a single rate that produces a } \\
\text { present value of total projected benefit payments equivalent to that obtained by } \\
\text { discounting projected benefit payments using (1) the long-term expected rate of } \\
\text { return on plan investments to the extent that current and expected future plan net } \\
\text { assets available for pension benefits are projected to be sufficient to make benefit } \\
\text { payments and (2) a high-quality municipal bond index rate for those payments that } \\
\text { are projected to be made beyond the point at which plan net assets available for } \\
\text { pension benefits are projected to be fully depleted. (See Chapter 4, paragraphs 14- } \\
\text { 23.) Do you agree with this view? Why or why not? }\end{array}$} \\
\hline ED: & \multicolumn{2}{|r|}{$\begin{array}{l}\text { As long as plan assets are projected to be sufficient to make the projected benefit } \\
\text { payments, governments would discount projected benefit payments using the long- } \\
\text { term expected rate of return on plan assets. If there is a point at which the plan } \\
\text { assets are projected to be insufficient to make the projected benefit payments, } \\
\text { governments would discount the projected benefit payments beyond that point } \\
\text { using a tax-exempt, high-quality } 30 \text {-year municipal bond index rate. (See } \\
\text { paragraphs 22-25). }\end{array}$} \\
\hline
\end{tabular}

In the ITC stage, all the proposed rates, except for the estimated long-term investment yield for the plan, are considered market-based rates. Therefore, we code the comment letter as opposing the proposal if the commenter chose (a) and as supporting the proposal if the commenter chose (b), (c), (d) or proposed an alternative market based discount rate (e). In the PV and ED stages, we code a comment letter as supporting a market determined discount rate if it indicates that a market based rate should be used to discount the portion of the pension liability not expected to be fully funded by future and current plan assets or if it suggests a stricter application that a market based rate should be used to discount all the liability. ${ }^{28}$ We code a comment letter as opposing a market determined discount rate if it advocates for the status quo practice of discounting the entire pension liability using long term expected rate of return on plan assets.

\begin{tabular}{|r|l|}
\hline 4. & $\begin{array}{l}\text { Employers participating in cost-sharing plans should recognize a proportionate } \\
\text { share of the net pension liability }\end{array}$ \\
\hline ITC: & $\begin{array}{l}\text { Does the relationship between a cost-sharing employer and the cost-sharing } \\
\text { multiple employer plan in which it participates differ enough in economic } \\
\text { substance from the relationship that a sole or agent employer has with the plan in }\end{array}$ \\
\hline
\end{tabular}

\footnotetext{
${ }^{28}$ The latter (i.e., discounting all pension liability using a market based rate) is advocated by most academics (e.g., Novy-Marx and Rauh, 2009, 2011) and credit rating agencies (e.g., Moody's, 2013).
} 


\begin{tabular}{|c|l|l|}
\hline & $\begin{array}{l}\text { which it participates to support different requirements with regard to liability and } \\
\text { expense recognition? Which of the following views best represents your view, and } \\
\text { why? }\end{array}$ \\
\hline a. & $\begin{array}{l}\text { The relationship does differ in economic substance, and current measurement, } \\
\text { recognition, and disclosure requirements appropriately account for the pension } \\
\text { cost and obligation of an employer in a cost-sharing plan. }\end{array}$ \\
\hline b. $\begin{array}{l}\text { The relationship does differ in economic substance, and current measurement } \\
\text { and recognition requirements are appropriate; however, additional disclosures } \\
\text { by cost-sharing employers are needed. }\end{array}$ \\
\hline \begin{tabular}{l} 
c. $\begin{array}{l}\text { The relationship does not differ in economic substance; a cost-sharing } \\
\text { employer has a long-term pension obligation based on the employment } \\
\text { exchange and should measure and recognize its obligation and expense in a } \\
\text { manner similar to that for sole and agency employers. }\end{array}$ \\
\hline PV:
\end{tabular} & $\begin{array}{l}\text { It is the Board's preliminary view that each employer in a cost-sharing plan is } \\
\text { implicitly primarily responsible for (and should recognize as its net pension } \\
\text { liability) its proportionate share of the collective unfunded pension obligation, as } \\
\text { well as its proportionate share of the effects of changes in the collective unfunded } \\
\text { pension obligation. (See Chapter 6.) Do you agree with this view? Why or why } \\
\text { not? }\end{array}$ \\
\hline ED: & $\begin{array}{l}\text { A government participating in a cost-sharing plan would report a liability in its } \\
\text { own financial statements that is equivalent to its long-term proportionate share of } \\
\text { the collective net pension liability. (See paragraphs 44-46). }\end{array}$ \\
\hline
\end{tabular}

In the ITC stage, we code a comment letter as opposing the proposal if the commenter chose option (a) or (b). 


\section{APPENDIX B:}

\section{Variable Definitions}

\begin{tabular}{|c|c|}
\hline $\mathrm{BBR}=$ & $\begin{array}{l}\text { The stringency of state balanced budget provisions based on the report of } \\
\text { the Advisory Commission on Intergovernmental Relations (1987) }\end{array}$ \\
\hline $\mathrm{COMP}=$ & $\begin{array}{l}\text { Indicator variable equal to } 1 \text { if the gubernatorial winning candidate's vote } \\
\text { is between } 49 \% \text { and } 51 \%\end{array}$ \\
\hline CORRUPT $=$ & $\begin{array}{l}\text { Indicator variable equal to } 1 \text { if the per capita corruption convictions of } \\
\text { local, state, and federal officials is greater than sample median and } 0 \\
\text { otherwise }\end{array}$ \\
\hline ANALYST $=$ & $\begin{array}{l}\text { Indicator variable equal to } 1 \text { if the commenter is a credit rating agency or } \\
\text { credit analyst and } 0 \text { otherwise }\end{array}$ \\
\hline $\mathrm{CS}=$ & $\begin{array}{l}\text { Indicator variable equal to } 1 \text { if the state sponsors cost-sharing pension } \\
\text { plans and } 0 \text { otherwise }\end{array}$ \\
\hline $\mathrm{DEBT}=$ & $\begin{array}{l}\text { Per capita net long term debt outstanding, where net long term debt } \\
\text { outstanding is the amount of total long term debt outstanding less total } \\
\text { offsets to debt (i.e., cash and security holdings in debt service fund or } \\
\text { sinking fund) }\end{array}$ \\
\hline DEFICIT $=$ & $\begin{array}{l}\text { Per capita general fund expenditures minus per capita general fund } \\
\text { revenues plus per capita midyear expenditure cuts and tax changes }\end{array}$ \\
\hline $\mathrm{ELE}=$ & $\begin{array}{l}\text { Indicator variable equal to } 1 \text { if a gubernatorial election occurs during the } \\
\text { year and } 0 \text { otherwise }\end{array}$ \\
\hline FUND_RATIO = & $\begin{array}{l}\text { The actuarial value of pension assets divided by the actuarial value of } \\
\text { pension liabilities }\end{array}$ \\
\hline INV_ASSUMP = & Reported expected rate of return on plan assets \\
\hline $\mathrm{LnPOP}=$ & Natural logathrim of state population (in millions) \\
\hline OPPOSE $=$ & $\begin{array}{l}\text { The extent to which the entity opposes the liability increasing new } \\
\text { accounting standards for public pension }\end{array}$ \\
\hline PENSIONL $=$ & Reported actuarial accrued liability scaled by total tax revenues \\
\hline PROTECTION = & $\begin{array}{l}\text { Indicator variable equal to } 1 \text { if the pension benefits of current public } \\
\text { employees are protected by state constitutions and } 0 \text { otherwise }\end{array}$ \\
\hline EMPLOYEE $=$ & $\begin{array}{l}\text { Indicator variable equal to } 1 \text { if the commenter is a public sector employee } \\
\text { and } 0 \text { otherwise }\end{array}$ \\
\hline USTRENGTH = & $\begin{array}{l}\text { The proportion of public sector state employees who are members of a } \\
\text { labor union or of an employee association similar to a union }\end{array}$ \\
\hline
\end{tabular}




\section{Table 1: Comment Letter Participation}

This table provides summary information on the constituents who submitted comment letters in response to GASB's due process documents. Panel A provides information on the full sample, including both financial statement preparers (state governments) and users (public employees, credit analysts, and citizens). Panel B provides additional information on user characteristics. All variables are defined in Appendix B.

Panel A: Total sample

$\begin{array}{llll}\text { ITC } & \text { PV } & \text { ED } & \text { Total }\end{array}$

$\begin{array}{llllll}\text { State Governments } & 31 & 27 & 16 & \mathbf{7 4}\end{array}$

Users

\begin{tabular}{rccccc} 
EMPLOYEE & 13 & 13 & 40 & 66 & 49 \\
ANALYST & 2 & 2 & 4 & 8 & 6 \\
CITIZEN & 23 & 23 & 35 & 81 & 66 \\
\cline { 2 - 6 } Total Users & $\mathbf{3 8}$ & $\mathbf{3 8}$ & $\mathbf{7 9}$ & $\mathbf{1 5 5}$ & $\mathbf{1 2 1}$
\end{tabular}

$\sim$ Distinct participants across all stages of due process

Panel B: User characteristics

\begin{tabular}{|lcccc|}
\hline & EMPLOYEE & ANALYST & CITIZEN & Total \\
\hline Individuals & & & & 79 \\
$\quad$ vs. Representative org. & 15 & 0 & 64 & 76 \\
& 51 & 8 & 17 & $\mathbf{1 5 5}$ \\
State-level user & & & 73 & 411 \\
$\quad$ vs. National org. & 37 & 7 & 8 & $\mathbf{1 5 5}$ \\
& 29 & & 16 & $\mathbf{2 4}$ \\
\# Represented states & & & 16 & \\
\end{tabular}

$\sim$ Distinct participants across all stages of due process 
Table 2: Lobbying Position by Type of Commenter

This table present descriptive information on constituent lobbying positions (OPPOSE) by constituent type. All variables are defined in Appendix B.

\begin{tabular}{|r|c|c|c|c|c|c|}
\hline & $\mathbf{n}$ & Mean & Median & Std. Dev. & Min & Max \\
\hline State Governments & 74 & 0.97 & 1 & 2.01 & -4 & 4 \\
\hline Users & & & & & & \\
\hline EMPLOYEE & 66 & 1.18 & 1 & 1.08 & -4 & 3 \\
\hline ANALYST & 8 & -1.25 & -1 & 1.75 & -1 & 4 \\
\hline CITIZEN & 81 & -0.73 & -1 & 1.64 & -3 & 4 \\
\hline
\end{tabular}


Table 3: Descriptive Information on State Governments

This table reports descriptive statistics on state governments that responded to the GASB's due process documents. All variables are defined in Appendix B.

\begin{tabular}{|l|c|c|c|}
\hline & Mean & Median & Std. Dev. \\
\hline PENSIONL & 3.92 & 3.78 & 1.33 \\
\hline FUND_RATIO & 81.33 & 81.39 & 0.31 \\
\hline INV_ASSUMP & 7.87 & 8.00 & 0.48 \\
\hline COST_SHARE & 0.66 & 1.00 & 701.38 \\
\hline DEFICIT & 38.51 & 102.30 & 228.92 \\
\hline DEBT & 476.28 & 454.00 & 2.76 \\
\hline BBR & 7.82 & 9.00 & 0.50 \\
\hline CORRUPT & 0.47 & 0.00 & 17.59 \\
\hline USTRENGTH & 31.92 & 28.40 & 1.09 \\
\hline LnPOP & 1.31 & 1.52 & 0.46 \\
\hline ELE & 0.30 & 0.00 & 0.20 \\
\hline COMP & 0.04 & 0.00 & \\
\hline
\end{tabular}


Table 4: Determinants of Lobbying Positions by State Governments

This table presents an analysis of the determinants of states' lobbying positions on the GASB's amendments to pension reporting proposals. All variables are defined in Appendix B. Reported in brackets are z-statistics calculated based on White heteroskedastic consistent standard errors and adjusted for clustering by state. ***, **, * represent 1,5 , and $10 \%$ level of significance, respectively.

\begin{tabular}{|c|c|c|c|}
\hline & \multicolumn{3}{|c|}{ Dependent variable $=$ OPPOSE } \\
\hline & [1] & [2] & [3] \\
\hline \multirow[t]{2}{*}{ PENSIONL } & -0.132 & -0.343 & -0.155 \\
\hline & {$[-0.609]$} & {$[-1.635]$} & {$[-0.588]$} \\
\hline \multirow[t]{2}{*}{ FUND_RATIO } & $-0.034 *$ & $-0.031 * *$ & $-0.036^{* *}$ \\
\hline & {$[-1.919]$} & {$[-2.001]$} & {$[-2.258]$} \\
\hline \multirow[t]{2}{*}{ INV_ASSUMP } & 0.474 & $1.710^{* *}$ & $1.488^{*}$ \\
\hline & {$[0.949]$} & [2.138] & [1.745] \\
\hline \multirow[t]{2}{*}{$\mathrm{CS}$} & 0.030 & 0.100 & -0.391 \\
\hline & {$[0.054]$} & [0.154] & {$[-0.602]$} \\
\hline \multirow[t]{2}{*}{ DEFICIT } & & $0.0004 * * *$ & $0.0005^{* *}$ \\
\hline & & {$[2.725]$} & [2.449] \\
\hline \multirow[t]{2}{*}{ DEBT } & & $0.002 *$ & 0.001 \\
\hline & & {$[1.803]$} & [0.861] \\
\hline \multirow[t]{2}{*}{ BBR } & & $0.282 * * *$ & $0.339 * *$ \\
\hline & & [3.039] & {$[2.392]$} \\
\hline \multirow[t]{2}{*}{ CORRUPT } & & & 0.399 \\
\hline & & & {$[0.687]$} \\
\hline \multirow[t]{2}{*}{ USTRENGTH } & & & $0.036^{*}$ \\
\hline & & & {$[1.696]$} \\
\hline \multirow[t]{2}{*}{ LnPOP } & & & $-0.399^{* * *}$ \\
\hline & & & {$[-2.004]$} \\
\hline \multirow[t]{2}{*}{ ELE } & & & -0.561 \\
\hline & & & {$[-0.653]$} \\
\hline \multirow[t]{5}{*}{ ELE*COMP } & & & -3.638 \\
\hline & & & {$[-1.307]$} \\
\hline & YES & YES & YES \\
\hline & 74 & 74 & 74 \\
\hline & 0.0698 & 0.0949 & 0.136 \\
\hline
\end{tabular}


Table 5: Determinants of Lobbying Positions by Users

This table presents an analysis of users' lobbying positions on the GASB's amendments to pension reporting proposals. All variables are defined in Appendix B. Reported in brackets are z-statistics calculated based on White heteroskedastic cluster-robust standard errors. $* * *, * *, *$ represent 1,5 , and $10 \%$ level of significance, respectively.

\begin{tabular}{|c|c|c|c|c|}
\hline Dependent variable $=$ OPPOSE & [1] & {$[2]$} & [3] & {$[4]$} \\
\hline \multirow[t]{2}{*}{ PENSIONL } & -0.894 & -0.937 & -0.364 & -0.237 \\
\hline & {$[-0.887]$} & {$[-0.984]$} & {$[-0.373]$} & {$[-0.245]$} \\
\hline \multirow[t]{2}{*}{ FUND_RATIO } & 0.169 & 0.198 & $0.384 * *$ & $0.396^{* *}$ \\
\hline & {$[1.472]$} & {$[1.519]$} & [2.359] & {$[2.394]$} \\
\hline \multirow[t]{2}{*}{ INV_ASSUMP } & -2.255 & $-3.002 *$ & -2.171 & -2.238 \\
\hline & {$[-1.111]$} & {$[-1.775]$} & {$[-0.403]$} & {$[-0.404]$} \\
\hline \multirow[t]{2}{*}{$\mathrm{CS}$} & 0.996 & 1.248 & 75.275 & 86.348 \\
\hline & {$[0.240]$} & {$[0.259]$} & {$[0.502]$} & {$[0.631]$} \\
\hline \multirow[t]{2}{*}{ DEFICIT } & & -0.002 & $-0.007 * *$ & $-0.007 * *$ \\
\hline & & {$[-1.232]$} & {$[-2.417]$} & {$[-2.019]$} \\
\hline \multirow[t]{2}{*}{ DEBT } & & 0.001 & 0.005 & 0.004 \\
\hline & & {$[0.300]$} & [0.829] & {$[0.770]$} \\
\hline \multirow[t]{2}{*}{ BBR } & & -0.645 & -2.172 & -2.607 \\
\hline & & {$[-0.866]$} & {$[-0.332]$} & {$[-0.436]$} \\
\hline \multirow[t]{2}{*}{ CORRUPT } & & & $7.705^{*}$ & $7.833^{*}$ \\
\hline & & & [1.827] & [1.880] \\
\hline \multirow[t]{2}{*}{ USTRENGTH } & & & -0.370 & -0.398 \\
\hline & & & {$[-1.191]$} & {$[-1.359]$} \\
\hline \multirow[t]{2}{*}{ LnPOP } & & & 40.129 & 46.788 \\
\hline & & & [0.459] & {$[0.586]$} \\
\hline \multirow[t]{2}{*}{ ELE } & & & 3.182 & 3.239 \\
\hline & & & [1.264] & {$[1.245]$} \\
\hline \multirow[t]{2}{*}{ ELE*COMP } & & & 5.473 & 5.424 \\
\hline & & & [1.218] & [1.146] \\
\hline \multirow[t]{2}{*}{ EMPLOYEE } & $3.631 * * *$ & $3.473 * * *$ & $3.602 * * *$ & $3.929 * * *$ \\
\hline & [4.170] & [4.106] & {$[4.150]$} & [4.227] \\
\hline \multirow[t]{2}{*}{ ANALYST } & -1.025 & -1.052 & -0.882 & -0.728 \\
\hline & {$[-1.529]$} & {$[-1.641]$} & {$[-1.519]$} & {$[-1.280]$} \\
\hline \multirow[t]{2}{*}{ PROTECTION } & & & & -60.326 \\
\hline & & & & {$[-0.537]$} \\
\hline \multirow[t]{2}{*}{ EMPLOYEE*PROTECTION } & & & & $-2.905 * * *$ \\
\hline & & & & {$[-3.082]$} \\
\hline State FE & YES & YES & YES & YES \\
\hline Year FE & YES & YES & YES & YES \\
\hline Observations & 155 & 155 & 155 & 155 \\
\hline Pseudo $\mathrm{R}^{2}$ & 0.217 & 0.220 & 0.242 & 0.247 \\
\hline
\end{tabular}




\section{Table 6: State Pension Reform Choices}

This table presents an analysis of pension reforms effectuated by state governments between 2011 and 2012. Panel A reports summary statistics and Panel B reports regression analysis. All variables are defined in Appendix B. Reported in brackets are z-statistics calculated based on White heteroskedastic consistent standard errors. ***,**, * represent 1,5 , and $10 \%$ level of significance, respectively.

Panel A: Summary statistics on state pension reform choices

\begin{tabular}{|lrr|}
\hline Reduce Employee Benefits & 23 \\
$\quad$ Affects only future employees & 15 & \\
$\quad$ Affects all employees & 8 & \\
Increase Funding & & 21 \\
Both Reduce Benefits and Increase Funding & & 11 \\
No Reform & & 17 \\
\hline
\end{tabular}


Panel B: Determinants of state pension reform choices

\begin{tabular}{|c|c|c|c|}
\hline Dependent Variable = & BEN_CUT & INC_FUND & $\begin{array}{c}\text { REFORMTYPE } \\
\text { (Benefit Cut=1, Increase } \\
\text { Funding=0) }\end{array}$ \\
\hline & [1] & [2] & [3] \\
\hline \multirow[t]{2}{*}{ D_OPPOSE } & $1.454 * *$ & -0.339 & $3.377 *$ \\
\hline & [1.999] & {$[-0.456]$} & [1.945] \\
\hline \multirow[t]{2}{*}{ DEFICIT } & $0.002 *$ & 0.002 & -0.023 \\
\hline & {$[1.825]$} & [0.913] & {$[-1.487]$} \\
\hline \multirow[t]{2}{*}{ DEBT } & $0.003^{*}$ & -0.001 & -0.000 \\
\hline & [1.798] & {$[-0.570]$} & {$[-0.004]$} \\
\hline \multirow[t]{2}{*}{ BBR } & -0.204 & $-0.265^{*}$ & -0.161 \\
\hline & {$[-1.427]$} & {$[-1.824]$} & {$[-0.496]$} \\
\hline \multirow[t]{2}{*}{ USTRENGTH } & -3.667 & 1.367 & $-10.730 * *$ \\
\hline & {$[-1.382]$} & {$[0.598]$} & {$[-2.220]$} \\
\hline \multirow[t]{2}{*}{ PROTECTION } & 0.505 & -1.557 & $\wedge$ \\
\hline & {$[0.563]$} & [-1.463] & $\wedge$ \\
\hline \multirow[t]{2}{*}{ PENSIONL } & -0.020 & -0.189 & 1.072 \\
\hline & {$[-0.089]$} & {$[-0.680]$} & {$[1.123]$} \\
\hline \multirow[t]{2}{*}{ FUND_RATIO } & 0.031 & -0.040 & $0.164 * *$ \\
\hline & [1.115] & {$[-1.421]$} & {$[2.140]$} \\
\hline \multirow[t]{2}{*}{ INV_ASSUMP } & 237.236 & 10.882 & $527.234 *$ \\
\hline & {$[1.581]$} & {$[0.077]$} & [1.729] \\
\hline \multirow[t]{2}{*}{$\mathrm{CS}$} & 0.261 & 0.492 & $-6.205^{* *}$ \\
\hline & {$[0.416]$} & {$[0.588]$} & {$[-2.127]$} \\
\hline \multirow[t]{2}{*}{ Intercept 1} & 20.942 & 4.614 & $-47.706 * *$ \\
\hline & [1.639] & {$[0.371]$} & {$[-2.102]$} \\
\hline \multirow[t]{2}{*}{ Intercept 2} & $22.900 *$ & & \\
\hline & [1.755] & & \\
\hline Model & Ordered Logit & Logit & Logit \\
\hline Observations & 50 & 50 & 20 \\
\hline Pseudo $\mathrm{R}^{2}$ & 0.177 & 0.134 & 0.496 \\
\hline
\end{tabular}

^PROTECTION takes a value of 1 for only two states in this reduced sample, both of which cut benefits for future employees. Accordingly, a coefficient on PROTECTION cannot be estimated. 